\title{
Eloquent Silences in Samuel Beckett's Waiting for Godot and Harold Pinter's The Dumb Waiter
}

\author{
Rawiya Kouachi \\ Department of English Language and Literature \\ Faculty of Letters and Languages \\ Mohamed Lamine Debaghine University, Setif 2, Algeria
}

\begin{abstract}
This paper analyzes Samuel Beckett's Waiting for Godot (1954) and Harold Pinter's The Dumb Waiter (2003) by focusing on their affinities and differences. It is an analytical literary study from a linguistic standpoint using Kenny's (2011) ideas. In addition to focusing on differences, the aim of this study is to scrutinize silence and its different meanings inasmuch as silence is a distinctive feature that groups and differentiates both plays. The study sheds light on a different aspect of research. Hence, besides focusing on interpreting speeches, this paper analyzes silences in both plays. It vindicates that silences are as important in literary interpretation as speeches. While Beckett's silences indicate the void of modern life, Pinter's silences convey threats and violence. Albeit much attention is given to verbal utterances and silences are generally neglected in terms of literary analysis, they are a sine qua non in terms of understanding Beckett's Waiting for Godot and Pinter's The Dumb Waiter and most importantly understanding the different languages of silence that greatly contribute to the whole meaning of both plays. Consequently, silences deserve much attention in literary interpretation as speeches and they are highly eloquent.

Keywords: Beckett's silence, differences, eloquence, Pinter's violent silence, void of modern life

Cite as: Kouachi, R. (2018). Eloquent Silences in Samuel Beckett's Waiting for Godot and Harold Pinter's The Dumb Waiter. Arab World English Journal for Translation \& Literary Studies, 2 (1).

DOI: http://dx.doi.org/10.24093/awejtls/vol2no1.13
\end{abstract}

